\title{
Translation, transcultural adaptation and validation of a scale of exposure to humanities among medical students
}

\section{Tradução, adaptação transcultural e validação da Escala de Exposição às Humanidades em estudantes de medicina}

\author{
Ilse Seubert Coelho Vieira' (1) | ilse.vieira@yahoo.com.br \\ Nathália Irffi Carvalho' (D) nathaliairffi@gmail.com \\ Antonio Carlos de Castro Toledo Júnior ${ }^{1}$ (D) toledoac@task.com.br \\ Eliane Perlatto Moura' (1) elianeperlatto@gmail.com
}

\begin{abstract}
Introduction: The humanities are associated with the improvement of medical students' personal qualities. To date, there are no research instruments that quantify the exposure of medical students have to the humanities. Hence, the availability of a questionnaire with such characteristics in Brazilian Portuguese sets a precedent for the planning and implementation of educational strategies and policies addressing this topic.

Objective: to translate and transculturally adapt the "HUMANITIES SCORE (LIFE EXPERIENCES + ATTITUDES) questionnaire, determine its validity and reliability, as well as identify the type of exposure to the humanities of the assessed population.

Method: The original version of the questionnaire, written in English, was translated according to what is recommended by the specialized literature, with the addition of some activities in the humanities field, as per the original authors' suggestion. The translated instrument underwent a pre-test with 31 medical students for semantic validation, followed by the application of its final version to 258 students. The exploratory and the confirmatory factorial analyses were applied to assess the instrument with its internal consistency was checked with Cronbach's Alpha coefficient.

Result: The final questionnaire was administered to the students to verify their type of exposure to the humanities. After the statistical tests were carried out, the final version of the instrument, named "Escala de Exposição às Humanidades" (EEH), included 17 items with Likert-scale responses with five options each, and obtained a Cronbach's alpha of 0.689 . The mean score of the students' exposure was $1.72 \pm 0.37$, being influenced by the period at medical school, the number of volunteer social activity experiences, the participation in religious groups, the practice of meditation, and the involvement in political activities. Variables such as female gender, engagement in previous actions related to the humanities before starting medical school and in religious ceremonies positively influenced the students' opinion about the importance of the humanities for the medical curriculum.
\end{abstract}

Conclusion: The EEH demonstrated reliability in its structure and content, allowing correlations between the students' exposure to humanities and their opinion about the importance of human sciences in the medical curriculum. It constitutes the first instrument that aims at measuring the humanities exposure rate in Brazil; however, further studies must be carried out, to better validate the instrument.

Keywords: Humanities; Medical Students; Translating; Validation Study; Medical Education.

\section{RESUMO}

Introdução: As humanidades estão associadas à melhora de qualidades pessoais dos estudantes de Medicina. Não existem, até o momento, instrumentos de investigação que quantifiquem a exposição dos estudantes de Medicina às humanidades, e a disponibilidade de questionário com essas características, em português do Brasil, permite planejar e implementar estratégias e políticas educacionais que abordem esse tema.

Objetivo: Este estudo teve como objetivos realizar a tradução e adaptação transcultural do Humanities Score (Life Experiences + Attitudes), determinar sua validade e confiabilidade, e identificar o perfil de exposição às humanidades da população estudada.

Método: A versão original do questionário, em inglês, foi traduzida conforme preconizado na literatura, com adição ao instrumento de algumas atividades no campo das humanidades, por sugestão dos autores do instrumento original. O instrumento traduzido foi submetido ao pré-teste, com 31 estudantes de Medicina, para a validação semântica, e, a seguir, a versão final foi aplicada a 258 discentes. A análise fatorial exploratória foi aplicada para avaliar o instrumento, e utilizou-se o alfa de Cronbach para avaliar a consistência interna.

Resultados: $O$ questionário final foi aplicado aos alunos para verificação do seu perfil de exposição às humanidades. Realizou-se análise estatística, e a versão final do instrumento denominado Escala de Exposição às Humanidades (EEH) constituiu-se de 17 itens com respostas do tipo Likert com cinco opções, cujo coeficiente alfa de Cronbach foi 0,689. A média de escore de exposição dos estudantes foi de 1,72 $\pm 0,37$, sendo influenciada por período em curso, realização de atividades sociais voluntárias, participação em grupos religiosos, prática de meditação e participação em atividades políticas. Observou-se ainda que as variáveis sexo feminino, exercício de atividades relacionadas com humanidades antes do curso e participar de cultos religiosos influenciaram positivamente na opinião sobre a importância atribuída às humanidades no currículo médico.

Conclusão: A EEH demonstrou estrutura e conteúdo confiáveis, permitindo correlacionar o comportamento dos alunos quanto à exposição às humanidades e a importância que atribuem à sua presença no currículo. Trata-se do primeiro instrumento que busca mensurar o índice de exposição às humanidades no Brasil, sendo necessários, entretanto, estudos adicionais para aprimorar a validação do instrumento.

Palavras-chave: Ciências Humanas; Estudantes de Medicina; Tradução; Estudo de Validação; Educação Médica.

1 Universidade José do Rosário Vellano, Belo Horizonte, Minas Gerais, Brazil.

Chief Editor: Rosiane Viana Zuza Diniz. Associate Editor: Maurício Abreu Pinto Peixoto.

Received on 02/02/21; Accepted on 10/15/21. | Evaluated by double blind review process. 


\section{INTRODUCTION}

The relationship between science and the humanities have existed throughout time and permeates the teaching and learning of Medicine since its origins ${ }^{1}$. The concept of "humanities" dates back to classical era, when education stimulated the expansion of human consciousness; however, education reached only part of the population². Over time, the educational process has been extended to an increasingly larger part of the population, following two basic lines of learning: science on the one hand and the humanities on the other, with the latter constituting the irreplaceable basis of thinking itself ${ }^{3}$. It was during the Renaissance that the term 'humanism' emerged and, since then, traditional studies have become more dynamic, based on the studia humanitatis program: the Renaissance man went in search of encyclopedic knowledge, for the development of both the body and the spirit ${ }^{2}$.

The regulation of the teaching and practice of Medicine began through laws and decrees published in 1224 by Emperor Frederick II in Italy. The medical curriculum at that time consisted of three years of philosophy, five years of Medicine and one year of practice ${ }^{2}$.

As Medicine is often called the "medical art", its learning involves, in addition to technical knowledge, diversified aspects such as communication, understanding of social, political, emotional and spiritual factors that affect the human experience, in addition to requiring the understanding not only of the illness, but also and essentially, of human suffering. Sir William Osler (1849-1919) uncompromisingly defended the practice of Medicine that was both technical and human and perfectly blended medical art and science 4 . And even Abraham Flexner (1866 - 1959), in his well-known report that was the basis of the creation of modern medical schools with a focus on biomedical knowledge and clinical training, acknowledged the need for a reconfiguration of medical education, recommending a response to the changes in scientific, social and economic circumstances, for the flourishing of medical education from one generation to the next. The flexibility and freedom to change, in fact, were an essential part of its message $\mathrm{e}^{5,6}$.

The humanities that are associated with the teaching of Medicine receive different definitions and boundaries, from curricular subjects common to training in human sciences, to exposure to the arts (active exposure, when the individual performs the activities, or passive exposure, when they appreciate them ${ }^{7}$ ). The arts have been related to human development, since the beginning, and increase empathy and communication skills, predisposing to ethical positions and gains in self-concept and motivation, favoring higher levels of tolerance in relation to the other ${ }^{8}$.
The medical student needs to learn a large volume of instrumental and emotional skills, in addition to extensive technical-scientific content, which are taught full-time. Therefore, free time to dedicate to social, leisure, sports and cultural activities, among others, is scarce, which interferes with the quality of life of these students ${ }^{9,10}$. There are proposals to alleviate this scenario, including curricular alterations ${ }^{11,12}$, such as the inclusion of activities related to the humanities ${ }^{7,13}$. Ousager and Johannessen point out that there are medical schools that include the humanities in their curricula, but it is difficult to analyze, with any degree of certainty, how much this inclusion effectively trains better physicians ${ }^{14}$. Other authors claim that the results of these mitigating measures lack a more objective analysis ${ }^{15}$ and that the absence of instruments able to assess the effectiveness of the humanities as an educational strategy makes it difficult to prove them ${ }^{16}$.

The importance of the subject is evident and the screened literature showed that there are no instruments in the Brazilian Portuguese language to quantify the exposure of medical students to contents and activities related to the humanities. Knowing the medical students' profile of exposure to the humanities thus becomes essential and can support curricular and/or extracurricular interventions that aim to increase the rates of exposure to activities related to the humanities. This study aimed to carry out the translation, transcultural adaptation and validation of the only foreign instrument that performs this type of measurement ${ }^{7}$.

\section{METHOD}

This is a cross-sectional study with a quantitative methodology, which aimed to cross-culturally adapt and validate, from the psychometric point of view, the "Humanities Score"7. This study was divided into two phases, the first being the translation and cross-cultural adaptation, and the second, the analysis of the psychometric properties of the translated instrument. It is noteworthy that permission was requested from the main author to translate the questionnaire. For the proposed study, a convenience, nonprobabilistic sampling was used, which considered, for the semantic validation, what has been recommended by Beaton et al., in which the translated version must be applied to a sample of 30 to 40 individuals from the target population ${ }^{17}$. The recommendations by Hair et al. were followed for the psychometric evaluation, in which they advise using five to ten individuals per evaluated item ${ }^{18}$. The inclusion criteria were: being regularly enrolled in the $1^{\text {st }}, 3^{\text {rd }}, 5^{\text {th }}$ or $7^{\text {th }}$ semesters of medical school and having understood, accepted and signed the Free and Informed Consent Form (FICF). The exclusion criteria were non-acceptance of the informed consent, minor 
individuals, refusal to participate or incomplete filling out of the questionnaire. The odd-numbered semesters of the preclinical period of the medical course were chosen because it is a non-probabilistic convenience sampling, including students who have more time to study, as they are not yet attending the internship in hospitals.

\section{The instrument}

A literature review carried out in the PubMed, Medline and SciELO databases did not identify any instrument, in the Brazilian Portuguese language, capable of measuring the exposure of medical students to the humanities. Considering this fact, it was decided to adapt and validate the "Humanities Score" instrument, developed by Mangione et al. 7 . The choice of instrument was based on the fact that it is the only instrument mentioned in the literature that has such approach.

\section{Translation and cross-cultural adaptation}

The translation and cross-cultural adaptation process were based on the steps suggested by Beaton et al. in 200017 (Figure 1).

- The translation from English into Brazilian Portuguese was performed by two certified translators, independent of each other: one was a layman on the subject assessed in the study and the other was specialized in Foreign Language Teaching, aiming to obtain two translated questionnaires (T1 and T2).

- $\quad$ T1 and T2 were compared and any discrepancies were analyzed and discussed by the researchers, resulting in the translation synthesis, in the Brazilian Portuguese language $(\mathrm{T} 1+2)$.

- The questionnaire synthesis $(T 1+2)$ was backtranslated into English by a third translator, resulting in the back-translation (BT) version. Beaton recommends two, but other authors claim that only one back-translation is sufficient ${ }^{17,19,20}$.

- The comparison of the back-translated (BT) version to the original instrument was carried out by consensus between the researchers and a teacher of the English language, making adjustments to preserve the content of the original instrument (content validation).

- To obtain the pre-final version of the questionnaire, a review was performed, paying special attention to elements such as instructions, addition of items, instrument format, adequacy of the response scale, existence of discrepancies, among others (review by the authors).

- The next step verified the semantic and cultural equivalence between the original version and the translated version of the questionnaire, by applying the pre-test (or pilot test), in which the respondents wrote what they understood of each item of the instrument, rewriting it, and/or offering adequacy suggestions. This step constituted the semantic and cross-cultural adaptation, which gave origin to the final version of the translated instrument (Figure 1).

\section{Psychometric Validation}

To assess the psychometric properties of the translated questionnaire, its final version, after the pre-test, was selfadministered to a convenience sample, consisting of 258 students from the first, third, fifth and seventh semesters of the undergraduate medical course at UNIFENAS-BH, between February and April of 2019. The questionnaire was handed to the students together with the Free and Informed Consent Form (FICF) and required approximately 10 minutes to be filled out.

Figure 1. Flowchart - Translation of the Humanities Score.

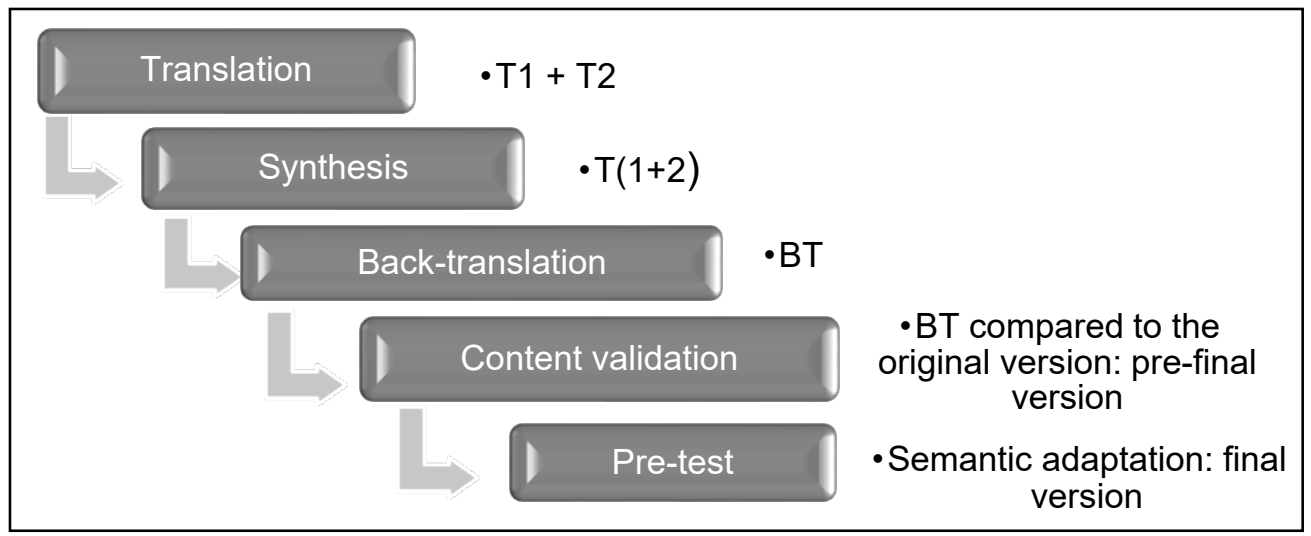

Source: Adapted from Beaton et al. (2002). 
The final version of the instrument contained 17 sociodemographic questions, which addressed age, medical school semester, gender, ethnicity, marital status, place of birth, religious practice, intended medical specialty, whether the student had a previous higher education degree, knowledge of a foreign language, and with whom they resided. It also addressed the performance of extracurricular activities, participation in voluntary social work, physical activity practice (the inclusion of these activities was suggested by the authors of the original questionnaire) and artistic activities practiced before starting medical school and their eventual interruption after the start of the course. This final version also contained the translated and adapted version of the Exposure to the Humanities Scale, consisting of 18 questions with answers in a Likert scale with 5 options (never, a few times a year, monthly, weekly and daily) and five questions regarding the opinion on the inclusion of the humanities in the medical curriculum, with answers on a Likert scale with 5 options (ranging from strongly disagree to strongly agree). Items with the opposite meaning to the predominant set of the evaluated questions had their scores inverted. To analyze the exposure index, the total mean of the scores was considered: the closer to five, the greater the exposure of students to the humanities.

The internal consistency of the final instrument was determined by calculating Cronbach's alpha, with values greater than $0.6^{20-22}$ being considered satisfactory. Methods to reduce the construct complexity through exploratory factor analysis were tested, but they were disregarded for being unsatisfactory in the case of this instrument.

\section{Ethical aspects}

This study was approved by the Research Ethics Committee - COEP/UNIFENAS, under Opinion number 3.037.771. All students involved in the study signed the FICF.

\section{RESULTS}

\section{Translation and cultural adaptation}

After the authors performed the steps of translation, synthesis, back-translation and review, the pre-final version of the instrument was obtained, without loss of content throughout these steps. Aiming to standardize the items, changes were implemented in the question format of the original questionnaire: transformation of ramified questions into simple questions, without changing their content and introduction of the option "never" in the frequency responses, which now contain the options: never, a few times a year, monthly, weekly and daily. All Likert scales were adapted to five response options ${ }^{23}$ and the scores ranged from one to five.

The pre-test was applied to 31 students from the $8^{\text {th }}$ semester of the medical school at Universidade José do Rosário Vellano (UNIFENAS-BH), who were randomly selected. Of these, $51.6 \%$ were females, with a mean age of $24.9 \pm 5.4$ years.

This step assessed the students' understanding of each item in the instrument. Suggestions and/or observations for modifications were presented in four items of the sociodemographic questionnaire: (1) in the item "Before starting the medical course, I regularly participated in: voluntary social activities/religious study groups/political activities/meditation/others, the option "none" was added; (2) in the item: "Before starting the medical course: I attended singing, dance, theater, concerts or musical concerts, read for pleasure / none", the option "movies" was added; (3) in the item "Performs extracurricular activities: none/ voluntary internship/remunerated internship/employee/ self-employed", the answer alternatives were changed to "yes" and "no", due to the possibility of performing other extracurricular activities not included in the options and (4) in the item "Reason for interrupting the practice of activities", the option "not applicable" was added, in case they were not interrupted. In the scale of exposure to the humanities, the item "Frequency of attendance at "musical concerts" was changed to "Frequency of attendance at "musical events". In the opinion scale on the importance of the humanities, the item "Not all curricula should include humanities" was changed to "All curricula should include humanities".

\section{Evaluation of the instrument's psychometric properties}

To assess the psychometric properties of the final version of the translated questionnaire, it was handed to 258 medical students, recruited from the $1^{\text {st }}, 3^{\text {rd }}, 5^{\text {th }}$ and $7^{\text {th }}$ semesters of the medical course, between February and April 2019, who agreed to participate in the study. Due to the established exclusion criteria, seven students were excluded for being underage and another 14 for not having adequately completed the questionnaire, thus totaling 237 participants. Of these, $32.9 \%$ were from the first semester, $24.1 \%$ from the third, $22.8 \%$ from the fifth and $21.1 \%$ from the seventh semester. The sociodemographic data showed a profile consisting of $61.6 \%$ of women, $74.7 \%$ of white ethnicity, $95.8 \%$ of single individuals, $68.8 \%$ who were originally from the city of Belo Horizonte or cities in the state of Minas Gerais. Of the 237 students, $76.4 \%$ declared some religious practice, $16.5 \%$ had attended another higher education course before entering medical school, 78.5\% had knowledge of the English language; $31.2 \%$ intended to specialize in surgery and $18.6 \%$ in Internal Medicine; $54.9 \%$ performed extracurricular activities and $65.8 \%$ performed individual physical activities (Table 1). 
Table 1. Sociodemographic characterization of the study participants

\begin{tabular}{|c|c|c|c|}
\hline \multicolumn{2}{|c|}{ Variables } & $\mathbf{n}$ & $\%$ \\
\hline \multirow{4}{*}{ Course semester } & $1^{\text {st }}$ semester & 78 & $32.9 \%$ \\
\hline & $3^{\text {rd }}$ semester & 57 & $24.1 \%$ \\
\hline & $7^{\text {th }}$ semester & 51 & $22.8 \%$ \\
\hline & $5^{\text {th }}$ semester & 50 & $21.1 \%$ \\
\hline \multirow{2}{*}{ Gender } & Female & 146 & $61.6 \%$ \\
\hline & Male & 91 & $38.4 \%$ \\
\hline \multirow{5}{*}{ Ethnicity } & White & 174 & $73.4 \%$ \\
\hline & Brown & 52 & $21.9 \%$ \\
\hline & Black & 6 & $2.5 \%$ \\
\hline & Yellow & 5 & $2.1 \%$ \\
\hline & Indigenous & 0 & $0.0 \%$ \\
\hline \multirow{3}{*}{ Marital status } & Single & 227 & $95.8 \%$ \\
\hline & Married & 6 & $2.5 \%$ \\
\hline & Common-law marriage & 4 & $1.7 \%$ \\
\hline \multirow{3}{*}{ Birth place } & Interior of Minas Gerais & 81 & $34.2 \%$ \\
\hline & Belo Horizonte/RMBH & 72 & $30.4 \%$ \\
\hline & Another state & 82 & $34.6 \%$ \\
\hline \multirow{2}{*}{ Religious practice } & Yes & 181 & $76.4 \%$ \\
\hline & No & 56 & $23.6 \%$ \\
\hline \multirow{5}{*}{$\begin{array}{l}\text { Intended medical } \\
\text { specialty }\end{array}$} & Undecided & 101 & $42.6 \%$ \\
\hline & Surgical & 74 & $31.2 \%$ \\
\hline & Clinical & 44 & $18.6 \%$ \\
\hline & Mental health & 11 & $4.6 \%$ \\
\hline & Family Medicine & 6 & $2.5 \%$ \\
\hline \multirow{2}{*}{$\begin{array}{c}\text { Has another HE } \\
\text { degree }\end{array}$} & No & 198 & $83.5 \%$ \\
\hline & Yes & 39 & $16.5 \%$ \\
\hline \multirow{5}{*}{$\begin{array}{l}\text { Knowledge of a } \\
\text { foreign language }\end{array}$} & English & 186 & $78.5 \%$ \\
\hline & Spanish & 55 & $23.2 \%$ \\
\hline & Another language & 6 & $2.4 \%$ \\
\hline & French & 5 & $2.1 \%$ \\
\hline & German & 2 & $0.8 \%$ \\
\hline \multirow{5}{*}{ Lives with } & $\begin{array}{l}\text { School of Medicine } \\
\text { fellow students }\end{array}$ & 89 & $37.6 \%$ \\
\hline & Family members & 80 & $33.8 \%$ \\
\hline & Alone & 49 & $20.7 \%$ \\
\hline & Other friends & 17 & $7.2 \%$ \\
\hline & Partner & 2 & $0.8 \%$ \\
\hline \multirow{2}{*}{$\begin{array}{l}\text { Performs } \\
\text { extracurricular } \\
\text { activities }\end{array}$} & Yes & 130 & $54.9 \%$ \\
\hline & No & 104 & $43.9 \%$ \\
\hline \multirow{5}{*}{$\begin{array}{c}\text { Practices physical } \\
\text { activities }\end{array}$} & Individual & 131 & $55.3 \%$ \\
\hline & Collective & 88 & $37.1 \%$ \\
\hline & None & 37 & $15.6 \%$ \\
\hline & $\begin{array}{l}\text { Individual with } \\
\text { personal trainer }\end{array}$ & 25 & $10.5 \%$ \\
\hline & Others & 8 & $3.4 \%$ \\
\hline
\end{tabular}

Exposure to the humanities, before entering medical school, was higher among passive exposure activities (going to the movies, music events and reading for pleasure) and the eventual interruption of some of these activities after entering the medical course was attributed to the scarcity of available time by $58.6 \%$ of the respondents (Chart 1 ).

When using construct complexity reduction methodologies based on exploratory factor analysis, it was observed that this analysis was not applicable to the model, concluding that the instrument could not be explained by the factor grouping method, as it was not possible to establish satisfactory correlations between the items. Therefore, the unidimensional model was adopted with the 17 items of analysis of the students' exposure to the humanities, with responses given in a Likert scale, with scores ranging from one to five. The calculation of Cronbach's alpha resulted in a value of 0.689 , considered satisfactory (Table 2 ).

When testing the instrument validity, it was observed that the students had an average index of exposure to the humanities of $1.72 \pm 0.37$, on an exposure scale with a maximum value of 5 , ranging between $24.8 \%$ and $68.6 \%$ of exposure. The habit of studying while listening to music was the activity that showed the highest average (2.84), followed by reading for pleasure (2.60), attending religious services (2.27), dancing (2.23) and attending musical events (2.15). Activities related to the production of visual arts, visiting museums/art galleries, playing a musical instrument, attending dance events or theatrical performances, writing for pleasure, meditating, participating in religious study groups, carrying out voluntary social activities and political activities, showed a frequency index with average scores ranging between 1.25 and 1.75 .

Exposure to the humanities was influenced by the course semester, with third-semester students showing significantly higher scores than those in the seventh semester $(p=0.011)$. Exposure was also influenced by the performance of voluntary activities $(p=0.020)$, participation in religious study groups $(p=0.001)$, practicing meditation $(p=0.001)$ and participation in political activities $(p=0.001)$. The other sociodemographic variables (gender, religious practices, place of birth, intended specialty, interruption of activities after starting medical school and having attended another course before starting medical school) did not influence exposure to the humanities. Regarding the students' favorable opinion about the importance attributed to the humanities, the variables that had a positive influence were female gender ( $p=$ 0.016), having interrupted the activities after starting medical school $(p=0.001)$ and participating in religious study groups $(p=0.016)$ (Table 3$)$. 
Chart 1. Sudents' exposure to the humanities before entering medical school.

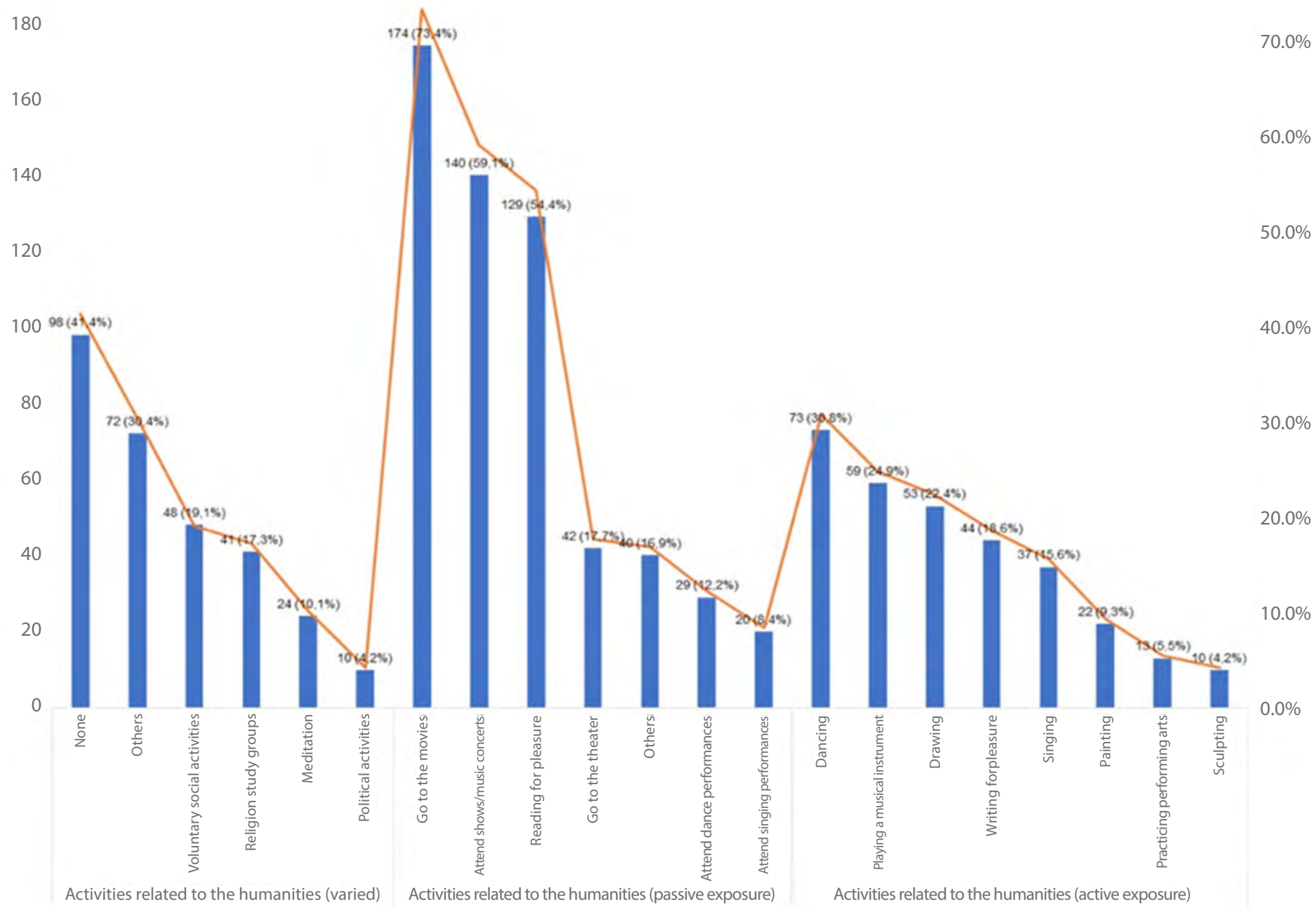

Table 2. Reliability analysis of the Exposure to Humanities Scale by the Cronbach's alpha test.

\begin{tabular}{|c|c|}
\hline Item & Cronbach' alpha if the item is removed \\
\hline Frequency of visual art production (drawing / painting / sculpting) & 0.667 \\
\hline Frequency of visits to art museums or art galleries & 0.677 \\
\hline Frequency of participation in a choir or musical group & 0.683 \\
\hline Frequency playing a musical instrument & 0.689 \\
\hline Frequency of attendance of dance performances & 0.680 \\
\hline Frequency of studying while listening to music & 0.686 \\
\hline Frequency of attendance of musical events & 0.690 \\
\hline Frequency of dance performances & 0.682 \\
\hline Frequency of performance in theatrical plays, except school activities & 0.685 \\
\hline Frequency of attendance at theatrical presentations & 0.673 \\
\hline Frequency of writing for pleasure & 0.663 \\
\hline Frequency of reading for pleasure & 0.663 \\
\hline Frequency of attendance of religious services & 0.681 \\
\hline Frequency of meditation practice & 0.657 \\
\hline Frequency of participation in religious study groups & 0.668 \\
\hline Frequency of participation in voluntary social activities & 0.665 \\
\hline Frequency of participation in political activities & 0.680 \\
\hline Cronbach's alpha for the entire questionnaire & 0.689 \\
\hline
\end{tabular}


Table 3. Comparison between sociodemographic data, profile of exposure to the humanities and the profile of the importance attributed to the humanities by the students.

\begin{tabular}{|c|c|c|c|c|c|c|c|}
\hline \multirow{2}{*}{\multicolumn{2}{|c|}{ Sociodemographic variables }} & \multicolumn{3}{|c|}{ Exposure to Humanities Scale } & \multicolumn{3}{|c|}{ Opinion Scale } \\
\hline & & Mean & $\begin{array}{l}\text { Standard } \\
\text { deviation }\end{array}$ & $\mathbf{p}$ & Mean & $\begin{array}{l}\text { Standard } \\
\text { deviation }\end{array}$ & $\mathbf{p}$ \\
\hline \multirow{4}{*}{$\begin{array}{l}\text { Currently attended } \\
\text { course semester }\end{array}$} & $1 \mathrm{st}$ & 1.74 & 0.36 & \multirow{4}{*}{${ }^{*} 0.011$} & 4.23 & 0.72 & \multirow{4}{*}{0.108} \\
\hline & $3 r d$ & 1.80 & 0.38 & & 4.03 & 0.80 & \\
\hline & 5 th & 1.64 & 0.33 & & 3.88 & 0.93 & \\
\hline & 70 & 1.62 & 0.35 & & 3.91 & 0.82 & \\
\hline \multirow{2}{*}{ Gender } & Female & 1.74 & 0.35 & \multirow{2}{*}{0.073} & 4.19 & 0.65 & \multirow{2}{*}{0.016} \\
\hline & Male & 1.67 & 0.41 & & 3.82 & 0.99 & \\
\hline \multirow{2}{*}{ Practices any religion? } & Yes & 1.74 & 0.37 & \multirow{2}{*}{0.084} & 4.04 & 0.84 & \multirow{2}{*}{0.931} \\
\hline & No & 1.64 & 0.36 & & 4.06 & 0.85 & \\
\hline \multirow{3}{*}{ Birth place } & Belo Horizonte and RMBH & 1.71 & 0.38 & & 4.08 & 0.77 & \multirow{3}{*}{0.424} \\
\hline & Interior of Minas Gerais & 1.68 & 0.32 & 0.705 & 3.95 & 0.89 & \\
\hline & Another state & 1.75 & 0.42 & & 4.12 & 0.79 & \\
\hline \multirow{5}{*}{$\begin{array}{l}\text { Intended medical } \\
\text { specialty }\end{array}$} & Internal Medicine & 1.66 & 0.26 & \multirow{5}{*}{0.051} & 4.00 & 0.92 & \multirow{5}{*}{0.081} \\
\hline & Surgical & 1.75 & 0.41 & & 4.12 & 0.77 & \\
\hline & Mental Health & 1.81 & 0.35 & & 4.42 & 0.43 & \\
\hline & Family Medicine & 2.01 & 0.27 & & 4.60 & 0.42 & \\
\hline & Not decided & 1.67 & 0.36 & & & 0.83 & \\
\hline \multirow{2}{*}{$\begin{array}{l}\text { Has interrupted the } \\
\text { activities? }\end{array}$} & No & 1.64 & 0.36 & \multirow{2}{*}{0.061} & 3.74 & 0.91 & \multirow{2}{*}{0.001} \\
\hline & Yes & 1.74 & 0.38 & & 4.16 & 0.75 & \\
\hline \multirow{2}{*}{$\begin{array}{l}\text { Has attended another } \\
\text { HE course? }\end{array}$} & Yes & 1.82 & 0.48 & \multirow{2}{*}{0.311} & 4.21 & 0.80 & \multirow{2}{*}{0.115} \\
\hline & No & 1.69 & 0.35 & & 4.02 & 0.82 & \\
\hline \multirow{2}{*}{$\begin{array}{l}\text { Performs voluntary } \\
\text { social activities? }\end{array}$} & Yes & 1.90 & 0.43 & \multirow{2}{*}{0.020} & 4.28 & 0.69 & \multirow{2}{*}{0.038} \\
\hline & No & 1.67 & 0.35 & & 3.99 & 0.84 & \\
\hline \multirow{2}{*}{$\begin{array}{l}\text { Participates in religious } \\
\text { study groups? }\end{array}$} & Yes & 2.02 & 0.36 & \multirow{2}{*}{0.001} & 4.34 & 0.72 & \multirow{2}{*}{0.001} \\
\hline & No & 1.65 & 0.34 & & 3.98 & 0.82 & \\
\hline Practices meditation? & Yes & 2.11 & 0.43 & 0.001 & 4.22 & 0.60 & 0.423 \\
\hline & No & 1.67 & 0.34 & & 4.03 & 0.84 & \\
\hline Participates in political & Yes & 2.39 & 0.52 & 0.001 & 4.30 & 0.42 & 0.524 \\
\hline activities? & No & 1.68 & 0.34 & 0.001 & 4.04 & 0.83 & $0.5<4$ \\
\hline Other activities & Yes & 1.79 & 0.37 & 0.013 & 4.09 & 0.73 & 0.889 \\
\hline ectict activities & No & 1.68 & 0.37 & S10.0 & 4.03 & 0.85 & 0.000 \\
\hline
\end{tabular}

Statistical tests: Variables with 2 categories: Mann-Whitney test; variables with 3 or more categories: Kruskal-Wallis test. Significance Level: $5 \%$.

\section{DISCUSSION}

The aim of the present study was the translation and sociocultural adaptation and psychometric validation of a scale of exposure to the humanities. The originality of this research lies in the fact that no instrument was found in the Brazilian literature that measured this exposure.

It is a concise scale that addresses exposure to different forms of art (literature, theater, music, dancing, visual arts, among others), allowing obtaining a wide range of information regarding medical students' active and passive exposure to humanities.
According to Borsa et al. ${ }^{19}$, the instrument adaptation process must consider the clarity and relevance of the concepts that belong to the original instrument, as well as the semantic, linguistic and contextual equivalence of the items. In this sense, the Exposure to Humanities Scale (EEH) showed satisfactory results after being modified and empirically tested in a group of medical students, proving to be an instrument that is easy to understand and apply. However, although qualitative methods are essential to ensure the adequacy of the adaptation process, it is necessary to assess the psychometric properties of the 
instrument ${ }^{20}$. In this study, the conducted statistical analysis showed that the EEH model presented a distribution of items in a single dimension, with a value of 0.689 found for Cronbach's alpha considered satisfactory for the reliability issue. For the analysis of exposure, the mean of the total scores obtained in the items ranging from 1 to 5 was considered: the closer to 5, the greater the exposure.

The results of applying the EEH in the present study showed that the average exposure of students was 1.72 (on a scale of 5). Similar results were obtained by Mangione et al. ${ }^{7}$ in a multicenter study carried out in five medical schools in the United States, which observed an average humanities exposure score of 1.32 (on a scale of 4).

It was also observed that although the students' exposure to humanities was considered low, the students consider the presence of the humanities to be important in the medical curriculum. According to Mairot et al. ${ }^{16}$, humanities based on the literature, cinema, music, opera, narratives and other modalities, by allowing a constructive encounter with values, experiences and diversities, become an instrument of learning and personal growth. Dell Amore Filho et al. ${ }^{15}$, when reviewing the teaching of humanization in medical schools, observed that there is an expectation that medical students have humanistic personal characteristics and that they will be able to apply them in the future in professional practice.

The debate on the crucial role of the humanities in the capacity to resize knowledge and discourses for the development of new concepts and new ways of doing Medicine is increasingly present today ${ }^{25}$. A humanist doctor or a "good doctor" must be able to combine scientific knowledge with interpretive capacity, understanding the other and having ethical sensitivity in their clinical practice ${ }^{26}$. In this sense, much has been studied and also speculated about the potentially positive effects that exposure of medical students to activities and contents related to the humanities can have on different aspects of their academic and personal life $e^{6,7}$. The different forms of art, literature, drama, music, reflect joy and sadness, being considered expressions of human creativity. Thus, participating in some type of artistic activity, whether as a spectator, reader or viewer, is part of being a complete human being ${ }^{26,27}$. Mangione et al. ${ }^{7}$ in 2018 observed that a greater exposure to the humanities was correlated with lower levels of burnout and better rates of positive personal qualities (empathy; tolerance for ambiguity, self-efficacy, emotional intelligence) ${ }^{7}$.

It can be inferred, based on these results, that exposure to the humanities improves positive personal aspects and reduces burnout, which may have an effect on the improvement of the student's quality of life, which, in turn, can positively interfere with their professional practice. The relationship built on a more reflective medical professional, endowed with a more humanistic vision and positioning, will enable greater patient adherence to the proposed procedures and possible achievement of better levels of satisfaction and even better clinical results.

In this study, the observation that the rate of exposure to the humanities decreases when the student progresses between the $1^{\text {st }}$ and $7^{\text {th }}$ semesters of the medical course is consistent with the information provided by the students, who declare that the interruption of the activities related to the humanities after entering medical school is due to little available time. These data are relevant, as studies point out that the "lack of time" is seen by medical students as responsible for the imposition of limitations on leisure, for desirable levels of rest and the practice of extracurricular activities, impacting their quality of life $\mathrm{e}^{28-30}$.

The practice of humanities needs to be encouraged throughout the course, satisfying the concern to educate medical professionals who are trained both in the technicalscientific aspects and in the aspect of human relations. In a review carried out by Mairot et al. $^{16}$, the detailed observation of paintings followed by discussions and reflections are mentioned as examples of activities that can be used for this purpose, aiming to develop the students' capacity for clinical observation; the use of literature to encourage the students critical reflections on humanistic values and professional practice; the use of theater as a tool that facilitates the learning of communication skills and the narrative of common clinical problems; the use of cinema through which students can explore their values, beliefs and attitudes towards the characteristics of professionalism.

The importance of the EEH, which addresses several aspects related to the humanities in the medical course, lies in the possibility of its use in future studies to provide elements for the development of the student's humanistic aspects and, consequently, of the medical professional. Moreover, it makes it possible to understand the factors that interfere with the exposure of medical students to the humanities, thus favoring the design of curricular strategies that are more adequate to the students' profile.

\section{CONCLUSIONS}

The final version of the EEH showed that it met the criteria of semantic, idiomatic, cultural and conceptual equivalence and showed adequate internal consistency, displaying evidence that it is adequate to assess the exposure of medical students to the humanities. As limitations of the study, we can mention that the participants are from the same private educational institution, which is why we suggest additional investigations with a more 
diversified sample. It is acknowledged that, because the validity evidence is not definitive, it is expected that further studies be carried out to confirm the results of this study and that the EEH can contribute to the knowledge of the behavior profile of medical students in relation to the humanities, thus allowing the development of management and improvement policies of the academic curriculum.

\section{AUTHORS' CONTRIBUTION}

Ilse Seubert Coelho Vieira participated in the study design, data collection, discussion of results, manuscript writing and review. Nathália Irffi Carvalho participated in the study design, data collection, and discussion of results. Antonio Carlos de Castro Toledo Júnior participated in the study design and data analysis. Eliane Perlatto Moura participated in the study design, data collection, discussion of results, manuscript writing and review, as well as the entire research orientation process.

\section{CONFLICTS OF INTEREST}

The authors declare no conflicts of interest.

\section{SOURCES OF FUNDING}

The authors declare no sources of funding.

\section{REFERENCES}

1. Machado GDC. Arte y medicina: una relación de mutualismo facultativo. Mirabilia Medicinæ. 2018,10:1-11 [access in 23 sep 2019]. Available from: https://www.revistamirabilia.com/sites/default/files/medicinae/pdfs/ med2018-01-

2. Azevedo VF. Uma breve história da arte na formação de médicos. látrico. 2015;15(35):40-8.

3. Chervel $A$, Compère MM. Les humanités dans l'histoire de l'enseignement français. Histoire de L'Éducation. 1997;74:5-38.

4. Craxi L, Giardina S, Spagnolo AG. A return to humane medicine: Osler's legacy. Infez Med. 2017;3:292-7.

5. Flexner A. Medical education in the United States and Canada. New York: Carnegie Foundation for the Advancement of Teaching; 1910.

6. Cooke M, Irby DM, Sullivan W, Ludmerer KM. American medical education 100 years after the Flexner report. NEJM. 2006;13:1339-44.

7. Mangione S, Chakraborti C, Staltari G, Harrison R, Tunkel AR, Liou KT, et al. Medical students' exposure to the humanities correlates with positive personal qualities and reduced burnout: a multi-institutional U. S. survey. J Gen Intern Med. 2018;33(5):628-34.

8. Catteral JS, Chapleau R, Iwanaga J. Involvement in the arts and human development: general involvement and intensive involvement in music and Theatre Arts. In: Fiske EB, editor. Champions of change: the impact of the arts on learning. Washington: Arts Education Partnership and President's Committee on the Arts and Humanities; 1999. p. 1-18 [access in 23 sep 2019]. Available from: http://artsedge.kennedy-center.org/ champions/pdfs/ChampsReport.pdf.
9. Lima RL, Soares MEC, Prado SN, Albuquerque GSC. Estresse do estudante de medicina e rendimento acadêmico. Rev Bras Educ Med. 2016;40(4):678-84.

10. Klier S. Lebensqualität von Medizinstudenten: Eine Studie zur Arbeitsbelastung, Gesundheit und der Bedeutung partnerschaftlicher Beziehungen im Medizinstudium [These]. Marburg: Universidade JustusLiebig Gießen; 2009.

11. Lyndon MP, Henning MA, Alyami H. Krishna S, Yu T-C, Hill AG. The impact of a revised curriculum on academic motivation, burnout, and quality of life among medical students. J Med Educ Curric Dev. 2017;4:1-8.

12. Song P, Jin C, Tang W. New medical education reform in China: towards healthy China 2030. Biosci Trends. 2017;11(4):366-9.

13. Cacchiarelli N, Catsicaris C, Cúneo MM, Damilano G, Dartiguelongue JB, Cunto $C$, et al. Las humanidades en la medicina: un camino para reflexionar acerca de la práctica clínica. Arch Argent Pediatr. 2017;115(5):99-104.

14. Ousager $\mathrm{J}$, Johannessen $\mathrm{H}$. Humanities in undergraduate medical education: a literature review. Acad Med. 2010;85(6):988-98.

15. Dell Amore Filho E, Dias RB, Toledo Jr ACC. Ações para a retomada do ensino da humanização nas escolas de Medicina. Rev Bras Educ Med. 2018;42(4):14-28.

16. Mairot LTS, Costa BBG, Heringer TPM, Borges RC, Moura, EP. As artes na educação médica: revisão sistemática da literatura. Rev Bras Educ Med. 2019;43(4):54-64.

17. Beaton DE, Bombardier C, Guillemin F, Ferraz MB. Guidelines for the process of cross-cultural adaptation of self-report measures. Spine (Phila Pa 1976). 2000 Dec 15;25(24):3186-91.

18. Hair JF, Anderson RE, Tatham RL, Black WC. Análise multivariada de dados. 5a ed. Porto Alegre: Bookman; 2005.

19. Borsa JC, Damásio BF, Bandeira DR. Adaptação e validação de instrumentos psicológicos entre culturas: algumas considerações. Paidéia. 2012;22(53):423-32

20. Eremenco SL, Cella D, Arnold BJ. A comprehensive method for the translation and cross-cultural validation of health status questionnaires. Eval Health Prof. 2005;28(2):212-32.

21. Fortes $C P D$, Araújo $A P Q C$. Check list para tradução e adaptação transcultural de questionários em saúde. Cad Saude Colet. 2019;27(2):202-9.

22. Landis JR, Koch GG. The measurement of observer agreement for categorical data. Biometrics. 1977;33(1):159-74.

23. Vieira S. Alfa de Cronbach. 2016 [access in 18 dec 2019]. Available from http://soniavieira.blogspot.com/2015/10/alfa-de-cronbach.html.

24. Likert R. A technique for the measurement of attitudes. Arch Psychol. 1932;22(140):5-55.

25. Rios, IC. Subjetividade contemporânea na educação médica: a formação humanística na medicina [tese]. São Paulo: Universidade de São Paulo; 2010.

26. Macnaughton J. The humanities in medical education: context, outcomes and structures. Med Humanit. 2000;26:23-30.

27. Mangione $S$, Kahn MJ. The old humanities and the new science at 100 Osler's enduring message. Cleve Clinic J Med. 2019;86(4):1-4.

28. Pasquali L. Psicometria: teoria dos testes na psicologia e na educação. 4a ed. Petrópolis: Vozes; 2011.

29. Figueiredo AM, Ribeiro GM, Reggianil ALM, Pinheiro BA, Leopoldo GO, Duarte JAH, et al. Percepções dos estudantes de medicina da UFOP sobre sua qualidade de vida. Rev Bras Educ Med. 2014;38(4):435-43.

30. Chazan ACS, Campos MR. Qualidade de vida de estudantes de medicina medida pelo WHOQOL-bref - UERJ, 2010. Rev Bras Educ Med. 2013;37(3):376-84. 